Joanna Ceglarska-Jóźwiak

Social Insurance Institution (ZUS)

The First Branch in Łódź

e-mail: joanna.ceglarska@zus.pl

\title{
Rola Zakładu Ubezpieczeń Społecznych w kształtowaniu postaw wobec idei ubezpieczenia społecznego
}

\section{The role of the Social Security Institution in shaping attitudes towards the idea of social insurance}

Social insurance is one of the social security techniques based on the principles of universality, compulsion, comprehensiveness and solidarity. The basis for the functioning of social insurance is the existence of a community of insured people - all those who earn a living through their own work. This community creates a contribution fund from which benefits are paid when certain social risks occur.

The proper functioning of social insurance relies on the mutual trust of all involved entities and the sense of joint responsibility for contributions to the Social Insurance Fund and the distribution of the fund. In particular, it is important that the insured trust the insurance institution and that the trust of this institution be ensured. However, we should remember that other entities, such as employers and doctors, are also involved. A lack of a sense of community means that abusing the Social Insurance Fund (failing to make contributions or extorting benefits) is perceived in society as resourcefulness, not as an unethical, blameworthy action, that damages the community of insured people and, consequently, also those who abuse it.

Therefore, the question arises, what actions should the Social Security Institution take to build trust in social insurance among society? How is it possible to create or strengthen the sense of community among the insured?

The Social Insurance Institution consistently implements various activities to build society's trust in social insurance and build a sense of community. In order to do this, the government must get more involved in insurance education, and the legislator should ensure legal stability and certainty.

Keywords: social insurance, Social Insurance Institution, Social Insurance Fund

JEL Classification: I3, K3 


\section{Wprowadzenie}

W artykule przeanalizowane zostały czynniki wpływające na kryzys zaufania do idei ubezpieczenia społecznego w Polsce oraz skutki tego kryzysu w postaci tolerancji dla nadużyć popełnianych na szkodę Funduszu Ubezpieczeń Społecznych. Przeprowadzona została analiza działań ustawodawcy oraz orzecznictwa sądowego w kontekście tychże nadużyć.

Warunkiem prawidłowego funkcjonowania ubezpieczenia społecznego jest wzajemne zaufanie wszystkich zaangażowanych podmiotów oraz poczucie współodpowiedzialności za fundusz składkowy i dystrybucję zgromadzonych w nim środków. Brak poczucia wspólnoty powoduje, że dokonywanie nadużyć w postaci omijania obowiązku składkowego i wyłudzania świadczeń postrzegane jest w społeczeństwie jako zaradność życiowa, a nie działanie nieetyczne, naganne, przynoszące szkodę wspólnocie ubezpieczonych, a w konsekwencji również osobom, które się ich dopuszczają.

W artykule przedstawione zostały również działania, wdrażane przez Zakład Ubezpieczeń Społecznych, mające na celu upowszechnienie wiedzy o ubezpieczeniach, uświadomienie ryzyka, wzmocnienie poczucia wspólnoty i współodpowiedzialności za fundusz składkowy. Działania te są potrzebne, choć w większości mają charakter długofalowy. Aby odniosły skutek, wskazane byłoby większe zaangażowanie państwa w edukację ubezpieczeniową oraz dbałość ustawodawcy o pewność i stabilność prawa w tej dziedzinie.

\section{Zasady ubezpieczenia społecznego}

Ubezpieczenie społeczne to technika zabezpieczenia społecznego oparta na zasadach powszechności, przymusowości i solidarności. Solidarność ma charakter zarówno poziomy, jak i pionowy (tzw. solidarność pokoleniowa). Podstawą funkcjonowania ubezpieczenia społecznego jest istnienie wspólnoty ubezpieczonych, do której należą, czy też powinny należeć, osoby uzyskujące środki utrzymania za pomocą pracy własnych rąk lub umysłu. Wspólnota ta tworzy fundusz składkowy, z którego wypłacane są świadczenia osobom przejściowo lub trwale niezdolnym do zarobkowania z powodu choroby, rodzicielstwa czy wieku, jak również członkom ich rodzin w przypadku utraty żywiciela. Ważnym elementem ubezpieczeń społecznych jest współfinansowanie składek na niektóre rodzaje ubezpieczeń przez pracownika i pracodawcę, ewentualnie przez zleceniobiorcę i zleceniodawcę.

W polskim społeczeństwie świadomość, na czym polega ubezpieczenie społeczne, jest bardzo niska. Świadczą o tym wyniki badania opinii publicznej przeprowadzonego w 2016 r. przez Millward Brown na zlecenie ZUS i Instytutu Spraw Publicznych (Marczak, 2016, s. 8-9). Aż 41\% ankietowanych, zapytanych o to, z jakiego źródła wypłacane są emerytury, odpowiedziało, że z budżetu Zakładu Ubezpieczeń Społecznych, a 27\%, że z budżetu państwa. Tylko 14\% potra- 
fiło prawidłowo wskazać relację pomiędzy ZUS-em a Funduszem Ubezpieczeń Społecznych i wiedziało, że z tego funduszu pochodzą środki na wypłatę emerytur. Aż $46 \%$ ankietowanych uważa, że składki na ubezpieczenia społeczne wpływają do budżetu ZUS-u.

Osoby płacące składki ubezpieczeniowe nie postrzegają się zatem w kategoriach wspólnoty ubezpieczonych. Traktują ZUS jako instytucję pobierającą składki i dysponującą nimi według własnego uznania (53\% uważa, że to ZUS decyduje o wysokości wypłacanych świadczeń, a 35\%, że odpowiada za system emerytalno-rentowy).

Jak pisze M. Łebkowska (2017, s. 22), „ubezpieczenie to wciąż niedoceniane w naszym społeczeństwie narzędzie zarządzania ryzykiem. Polacy nadal mają problemy ze zrozumieniem jego roli w życiu gospodarczym" (dotyczy to nie tylko ubezpieczenia społecznego, ale ubezpieczeń w ogóle).

\section{Wzajemne zaufanie i współodpowiedzialność}

Warunkiem prawidłowego funkcjonowania ubezpieczenia społecznego jest wzajemne zaufanie wszystkich zaangażowanych podmiotów oraz poczucie współodpowiedzialności za fundusz składkowy i dystrybucję zgromadzonych w nim środków. Szczególnie ważne jest zaufanie ubezpieczonych do instytucji ubezpieczeniowej oraz instytucji do ubezpieczonych.

W proces realizacji przepisów ubezpieczeniowych zaangażowane są również inne podmioty - pracodawcy $\mathrm{i}$ inne osoby korzystające $\mathrm{z}$ pracy najemnej oraz lekarze. Brak poczucia wspólnoty powoduje, że dokonywanie nadużyć w postaci uchylania się od obowiązku składkowego i wyłudzania świadczeń jest postrzegane jako zaradność życiowa, a nie działanie nieetyczne i naganne, przynoszące szkodę wspólnocie ubezpieczonych, w tym również osobom, które się owych nadużyć dopuszczają.

Problem wzajemnego zaufania można przedstawić na przykładzie zasiłku chorobowego wypłacanego pracownikowi na postawie zwolnienia lekarskiego. Dokument ten jest jednocześnie usprawiedliwieniem nieobecności w pracy. Lekarz wypisuje zwolnienie, wierząc ubezpieczonemu, że zgłaszane przez niego objawy i inne dane podawane w wywiadzie są prawdziwe. Pracodawca i instytucja ubezpieczeniowa działają w zaufaniu do lekarza, zakładając, że wystawione przez niego świadectwo niezdolności do pracy jest zasadne, oraz w zaufaniu do ubezpieczonego, że nie nadużywa zwolnienia od pracy, wykorzystując je niezgodnie z jego celem. Ubezpieczony wierzy, że pracodawca czy zleceniodawca wypełnił ciążące na nim obowiązki wobec instytucji ubezpieczeniowej, która wypłaci terminowo świadczenie zapewniające mu środki utrzymania. Instytucja ubezpieczeniowa zakłada, że pracodawca i pracownik nie działają w zmowie mającej na celu wyłudzenie nienależnego zasiłku. Oni z kolei oczekują, że instytucja udzieli im pełnej i rzetelnej informacji o zasadach podlegania ubezpieczeniu i warunkach nabywania prawa do świadczeń oraz że będzie działała zgodnie obowiązującymi 
przepisami. Wystarczy nielojalne zachowanie jednego z uczestników opisanej sytuacji, aby doszło do nieuzasadnionej wypłaty świadczenia kosztem innych osób tworzących fundusz składkowy albo niesłusznego pozbawienia ubezpieczonego należnego mu zasiłku. W obydwu przypadkach dochodzi do wykształcenia się negatywnej postawy wobec instytucji ubezpieczeniowej oraz idei ubezpieczenia społecznego.

W razie wykrycia nadużycia po stronie instytucji pojawia się impuls do nasilenia kontroli w zakresie zarówno prawidłowości wykorzystywania zwolnień, jak i składanych przez płatnika dokumentów zgłoszeniowych i rozliczeniowych. Powoduje to utrwalenie się wizerunku zakładu jako organu represyjnego, dbającego wyłącznie o interes fiskalny, nękającego przedsiębiorców i ubezpieczonych drobiazgowymi kontrolami.

Jak wykazuje przywoływane już badanie opinii publicznej z 2016 r., tylko 7\% Polaków prezentuje zadowalający poziom wiedzy na temat ubezpieczeń społecznych. Ocenami w tym zakresie rządzą zatem emocje, wśród których dominuje niepewność co do wysokości przyszłych świadczeń (Marczak, 2016, s. 17, 36). Ponad połowa ankietowanych wyraziła przekonanie o nieadekwatności świadczeń do wysokości opłacanych składek (s. 25).

Kryzys zaufania do idei ubezpieczenia społecznego przyczynia się do ucieczki od obowiązku składkowego i powszechnego tolerowania nadużyć dokonywanych na szkodę Funduszu Ubezpieczeń Społecznych. Kryzys ten wynika również z ogólnie niskiego poziomu kapitału społecznego w Polsce. Według badań przeprowadzonych przez World Values Survey w 2012 r. w Polsce zaufanie do ludzi deklarowało $22,2 \%$ ankietowanych, zaufanie do rządu - $16,1 \%$, do parlamentu $-11 \%$. Dla porównania w Niemczech wskaźniki te wynosiły odpowiednio 44,6\%, 44,4\%, 43,5\% (World Values Survey, wave 6, 2010-2014). Jest to częściowo uzasadnione uwarunkowaniami historycznymi, które doprowadziły do rozwoju ekskluzywnych, bliskich i nieformalnych sieci często ograniczonych do rodziny i najbliższych znajomych, a nie sprzyjały rozwojowi zaufania ogólnoludzkiego, do instytucji i oddolnych inicjatyw obywatelskich (Jędrych \& Berniak-Woźny, 2018, s. 40). Nic dziwnego, że na ubezpieczenia społeczne większość społeczeństwa patrzy przez pryzmat partykularnych interesów - własnych i najbliższego otoczenia - i uważa za usprawiedliwione działania służące uzyskaniu jak najwyższych świadczeń przy jak najmniejszych obciążeniach składkowych.

Podkreślić należy, że nie każde działanie mające na celu zmniejszenie wysokości opłacanych składek ubezpieczeniowych jest nadużyciem. Można tu nawiązać do koncepcji optymalizacji na gruncie prawa podatkowego. W piśmiennictwie wyróżnia się trzy formy tzw. oporu podatkowego (Felis \& Szlęzak-Matusewicz, 2018, s. 86-92):

(1) optymalizację podatkową zgodną zarówno z prawem, jak i z celem ustawy,

(2) szkodliwą, agresywną optymalizację podatkową stanowiącą obejście prawa, zgodną z treścią ustawy, ale niezgodną z jego celem,

(3) uchylanie się od opodatkowania poprzez podejmowania działań zakazanych przez prawo, np. fałszowanie ksiąg podatkowych. 
Granica pomiędzy dwoma ostatnimi rodzajami zachowań, zarówno w zakresie podatków, jak i ubezpieczeń społecznych, jest płynna. Niekiedy przedsiębiorcy podejmujący działania $\mathrm{w}$ celu zmniejszenia obciążeń składkowych pozostają w błędnym przekonaniu o ich zgodności z prawem. Przekonanie to wynika na przykład $\mathrm{z}$ nieuświadomienia sobie, że o rodzaju umowy cywilnoprawnej nie decyduje nazwa nadana jej przez strony, ale jej faktyczna treść lub że strony mogą względnie swobodnie kształtować swoje stosunki na gruncie prawa cywilnego, ale nie mogą zmieniać zasad podlegania ubezpieczeniom społecznym, wynikającym z przepisów o charakterze publicznoprawnym. Oznacza to, że jeśli strony faktycznie zawrą umowę, z tytułu której osoba wykonująca pracę podlega obowiązkowi ubezpieczenia, to nie mogą się umówić co do tego, że umowa ta nie będzie rodziła obowiązku ubezpieczenia.

Często w odbiorze społecznym stosowanie umów pozornych czy błędne nazywanie umów w celu zmniejszenia wysokości składek jest uznawane za zgodne z prawem lub co najwyżej kwalifikowane jako jego obejście. Uznać to jednak należy za działanie polegające na umyślnym wprowadzaniu w błąd instytucji ubezpieczeniowej co do właściwego charakteru stosunku prawnego pomiędzy stronami, nie jest zatem zgodne z prawem i powinno być zarówno pod względem prawnym, jak i moralnym oceniane na równi z fałszowaniem dokumentów.

Należy zauważyć, że nie ma możliwości precyzyjnego uregulowania prawem wszystkich możliwych sytuacji faktycznych. Dążenie do tego prowadziłoby do zbytniej kazuistyki i bezduszności prawa. Nawet w systemie norm publiczno-prawnych musi pozostawać margines dla ocen czysto moralnych. Ostatecznie zatem prawidłowe funkcjonowanie systemu ubezpieczeń zależy od upowszechniania zasad społecznej odpowiedzialności biznesu. Etyka w biznesie zależy zaś od ludzi, czyli przedsiębiorców i menedżerów, a w szerszym kontekście - od kondycji moralnej społeczeństwa (Łączak, 2018, s. 57-58).

\section{Niestabilność i niepewność prawa jako czynnik osłabiający zaufanie do idei ubezpieczenia społecznego}

Zakład Ubezpieczeń Społecznych jako popularyzator idei ubezpieczeniowych ma utrudnione zadanie $\mathrm{z}$ uwagi na nieprzyjazne środowisko, w jakim zmuszony jest działać. Przepisy ubezpieczeniowe cechują się niestabilnością, co wynika z przyczyn politycznych (uleganie naciskom określonych grup i środowisk), jak i z konieczności reagowania przez ustawodawcę na zjawiska patologiczne, konieczności doprecyzowania przepisów budzących wątpliwości czy dostosowania rozwiązań legislacyjnych do utrwalonego orzecznictwa sądowego.

Ustawa z 1998 r. o systemie ubezpieczeń społecznych, zwana dalej ustawą systemową ${ }^{1}$, od momentu uchwalenia była nowelizowana 144 razy, tj. średnio co 2 miesiące, przy czym większość nowelizacji dotyczyła więcej niż jednego przepisu.

\footnotetext{
${ }^{1}$ Ustawa z dnia 13.10.1998 r. o systemie ubezpieczeń społecznych (t. jedn. Dz.U. 2019, poz. 300 ze zm.).
} 
Ustawa z 1998 r. o emeryturach i rentach z FUS, zwana dalej ustawą emerytalną ${ }^{2}$, była $\mathrm{w}$ tym czasie nowelizowana 100 razy. Tak częste zmiany prawa $\mathrm{w}$ dziedzinie istotnej dla obywateli działają destrukcyjnie na ich zaufanie do systemu ubezpieczeń. Trudno wymagać od ubezpieczonych i płatników składek długofalowego myślenia, planowania przyszłości i przewidywania ryzyk w sytuacji, gdy brak jest pewności co do tego, jak podjęte przez nich decyzje wpłyną w pewnej perspektywie czasowej na ich prawa, obowiązki czy interesy życiowe. Jak przekonać osoby aktywne zawodowo do rzetelnego opłacania składek emerytalnych, skoro nie wiadomo, na jakich zasadach będą przyznawane i obliczane emerytury? Nie wiemy bowiem, jakie przepisy będą obowiązywały, gdy osoby te osiągną stosowny wiek, a nawet jaki wiek emerytalny będzie wówczas obowiązywał.

Podkreślenia wymaga, że przepisy ubezpieczeniowe są na ogół skomplikowane i trudne do interpretacji nawet dla osób zajmujących się zawodowo tą dziedziną prawa. Wynika to ze słabej techniki legislacyjnej, tj. nadmiernej liczby odesłań, braku staranności przy stosowaniu znaków interpunkcyjnych, używania zbyt zawiłego języka i ignorowania zasad logiki. Rekonstrukcja normy jest często zabiegiem złożonym, wymagającym sięgnięcia do kilku czy nawet kilkunastu przepisów tej samej ustawy lub innych ustaw. W dodatku ustawodawca nakłada wiele obowiązków na płatników składek, którzy są osobami fizycznymi bez wykształcenia prawniczego i nie są w stanie wywiązać się z tych obowiązków bez skorzystania z profesjonalnej pomocy.

Przykładem niestabilności prawa są działania ustawodawcy zmierzające do wyeliminowania zjawiska polegającego na wykorzystywania tzw. zbiegów tytułu ubezpieczenia do omijania obowiązku składkowego. Skutkiem (między innymi) tych działań jest „rozrost” art. 9 ustawy systemowej, który w tekście pierwotnym miał 7 ustępów, a obecnie ma ich 21 (dodano ust. 1a, 1b, 1c, 1d, 2a, 2b, 2c, 4a, 4b, 4c, 6a, 6b, 8 i 9).

W pierwotnej wersji tego przepisu pracownik, który posiadał również inny tytuł ubezpieczenia (na przykład działalność gospodarczą lub umowę-zlecenie), był obowiązany opłacać składki na ubezpieczenie społeczne tylko z tytułu umowy o pracę. Osoby zainteresowane optymalizacją składkową zawierały umowy o pracę (na ogół pozorne) z symbolicznym wynagrodzeniem, aby uniknąć nieporównanie wyższych składek, jakie musiałyby opłacać z tytułu działalności stanowiącej ich faktyczne źródłoutrzymania. Ustawodawca zareagował na to, wprowadzając od 30.12.1999 r. zasadę, że warunkiem niepodlegania ubezpieczeniu $\mathrm{z}$ innych tytułów jest uzyskiwanie z tytułu umowy o pracę co najmniej minimalnego wynagrodzenia. Wówczas przedsiębiorcy zaczęli zawierać pozorne umowy-zlecenia z symbolicznym wynagrodzeniem i dokonywać wyboru tych umów jako tytułu ubezpieczenia zamiast prowadzonej działalności (do czego uprawniał ich ust. 2 omawianego przepisu). Spowodowało to konieczność wprowadzenia od 1.11.2005 r. ust. 2a, w którym ustawodawca zastrzegł, że aby nie podlegać ubezpieczeniu z tytułu prowadzonej działalności, trzeba uzyskiwać z tytułu umowy-zlecenia wynagrodzenie równe co najmniej najniższej podstawie wymiaru

\footnotetext{
${ }^{2}$ Ustawa z dnia 17.12.1998 r. o emeryturach i rentach z Funduszu Ubezpieczeń Społecznych (t. jedn. Dz.U. 2018, poz. 1270).
} 
składek obowiązującej daną osobę z tytułu działalności. Wówczas „umowy-zlecenia” zostały „,przekwalifikowane” na umowy o pracę nakładczą. Nakładcy nie są objęci przepisami o minimalnym wynagrodzeniu, a umowa o pracę nakładczą, niezależnie od podstawy wymiaru składek, zwalniała z obowiązku ubezpieczenia z tytułu działalności gospodarczej.

Sądy ubezpieczeń społecznych masowo uznawały te umowy (na ogół opiewające na kwotę $50 \mathrm{zł}$ miesięcznie) za pozorne, zatem niewywołujące skutków prawnych (tak samo, jak to czyniły w przypadku umów-zleceń). Przedsiębiorcy, którzy zdecydowali się na taką optymalizację, pozostali z ogromnym zadłużeniem wobec ZUS, wynikającym z konieczności opłacenia wraz odsetkami składek z tytułu działalności gospodarczej. Była to jedna z przyczyn ogłoszenia późniejszej abolicji składkowej. Problem umów o pracę nakładczą został rozwiązany 1.03.2009 r. poprzez wprowadzenie ust. 2b, brzmiącego analogicznie, jak w przypadku umów-zleceń.

Podobny, tyle że bardziej skomplikowany proces, można prześledzić w przypadku działań zmierzających do unikania składek z tytułu umów-zleceń.

Warto także zwrócić uwagę na problem kobiet urodzonych w 1953 r. Były one ostatnim rocznikiem uprawnionym do przejścia na tzw. wcześniejsze emerytury z tytułu ukończenia 55 lat. Gdy jednak osiągnęły ustawowy wiek emerytalny 60 lat, obowiązywał już wprowadzony 1.01 .2013 r. przepis art. 25 ust. 1b ustawy emerytalnej, nakazujący pomniejszanie kapitału początkowego o kwotę wypłaconych wcześniejszych emerytur. Wyrokiem z dnia 6.03.2019 r. (P 20/16) Trybunał Konstytucyjny uznał, że art. 25 ust. $1 \mathrm{~b}$ ustawy emerytalnej jest niezgodny z art. 2 Konstytucji RP w zakresie, w jakim dotyczy kobiet, które przed dniem 1 stycznia 2013 r. nabyły prawo do emerytury na podstawie art. 46 tej ustawy.

Należy podzielić stanowisko Rzecznika Praw Obywatelskich w tej sprawie, który uznał, że zakwestionowana regulacja prawna prowadzi do naruszenia bezpieczeństwa prawnego jednostki, a przez to jest niezgodna $\mathrm{z}$ konstytucyjną zasadą zaufania do państwa i stanowionego przez nie prawa. Zasada ochrony zaufania jednostki do państwa wyraża się w takim stanowieniu i stosowaniu prawa, aby jednostka miała możliwość decydowania o swoim postępowaniu na podstawie pełnej znajomości przesłanek działania organów państwa, a zarazem konsekwencji prawnych, jakie postępowanie to może za sobą pociągnąć. Kobiety z roczników 1949-1953, odchodząc na wcześniejszą emeryturę, nie miały wiedzy, że zmienią się zasady wyliczania ich przyszłych świadczeń. Kobiety z rocznika 1953, które przed 1 stycznia 2013 r. nabyły i zrealizowały prawo do wcześniejszej emerytury, zmuszone zostały do nowej, mniej korzystnej dla nich regulacji. Zostały narażone na prawne skutki, których nie mogły przewidzieć w momencie podejmowania decyzji o skorzystaniu z prawa do wcześniejszej emerytury (Stanowisko RPO w sprawie P 20/16).

Przykładem niejasności prawa są tzw. przedsiębiorcze matki. Chodzi o kobiety przebywające na zasiłku macierzyńskim lub urlopie wychowawczym z tytułu zatrudnienia na umowę o pracę, a jednocześnie prowadzące działalność gospodarczą. Na gruncie art. 9 ust. 6 ustawy systemowej pojawiły się wątpliwości co do tego, czy są one zobowiązane do opłacania składek na ubezpieczenia społeczne 
$\mathrm{z}$ tytułu prowadzonej działalności. Zapadały w tym zakresie sprzeczne orzeczenia Sądu Najwyższego (wyrok SN z 20.10.2005 r., I UK 63/05, LEX nr 375727; wyrok SN z 18.01.2005 r., II UK 128/04, OSNP 2005/15/233, M.P.Pr.-wkł. 2005/11/17; wyrok SN z 14.06.2005 r., I UK 280/04, OSNP 2006/3-4/61; uchwała 7 sędziów SN z 23.05.2006 r., III UZP 2/06, OSNP 2007/1-2/20, Prok.i Pr.-wkł. 2007/4/37, Biul.SN 2006/5/29, M.P.Pr. 2006/11/609). Ostatecznie interweniował ustawodawca, wprowadzając od 1.09.2009 r. zasadę, że przedsiębiorca pobierający zasiłek macierzyński podlega ubezpieczeniom społecznym tylko z tytułu tego zasiłku, nie musi zatem opłacać składek z tytułu działalności gospodarczej (art. 9 ust. 1c ustawy systemowej). Do tego czasu panowała niepewność co do treści obowiązującego prawa, a płatnicy nie wiedzieli, czy ich postępowanie polegające na uiszczaniu czy nieuiszczaniu należności wobec FUS jest prawidłowe, skoro nawet Sąd Najwyższy nie był w stanie zająć jednoznacznego stanowiska.

\section{Negatywne aspekty abolicji składkowych}

W 2009 r. ustawodawca zdecydował się na abolicję składkową dla „przedsiębiorczych matek", umarzając zadłużenie tym, które nie opłacały składek, opierając się na interpretacji przepisów zastosowanej przez SN z wyrokach z 18.01.2005 r., II UK 128/04 i 20.10.2005 r., I UK 63/05. Umorzenie następowało wprawdzie na wniosek, ale było obligatoryjne i niezależne od spełnienia dodatkowych przesłanek, na przykład w postaci trudnej sytuacji majątkowej wnioskodawczyni. Takie postępowanie ustawodawcy można by uznać za słuszne, biorąc pod uwagę wątpliwości co do treści obowiązującego prawa. Jednak abolicja mogła wywołać poczucie niesprawiedliwości u tych przedsiębiorców, którzy opłacali składki w okresie pobierania zasiłku macierzyńskiego, opierając się na wykładni ZUS i SN z orzeczenia z dnia 14.06.2005 r., I UK 280/04 oraz uchwale SN z 23.05.2006 r., III UZP 2/06. Opłacone składki zostały bowiem uznane za należne i nie było możliwości ich odzyskania. W społeczeństwie mogło wykształcić się przekonanie, że w sytuacji wątpliwej lepiej nie płacić składek i liczyć na nową interpretację lub nowelizację przepisów czy też kolejną abolicję. Nasuwa się myśl, że w opisanej sytuacji ustawodawca powinien był ograniczyć się do umorzenia odsetek od nieopłaconych składek. Byłoby to uzasadnione stanem niepewności prawnej i brakiem winy po stronie płatnika, a jednocześnie nie sprzyjałoby powstaniu przekonania o nieopłacalności wywiązywania się z obowiązku opłacania składek.

W 2012 r. ustawodawca wprowadził kolejną abolicję dotyczącą składek za lata 1999-20094, obwarowując ją jedynie warunkiem spłacenia w ciągu roku należności niepodlegających umorzeniu. Spełnienie tego warunku powodowało

\footnotetext{
${ }^{3}$ Ustawa z 24.04.2009 r. o zmianie ustawy o systemie ubezpieczeń społecznych oraz ustawy Prawo bankowe (Dz.U.2009.71.609 ze zm.).

${ }^{4}$ Ustawa z 9.11.2012 r. o umorzeniu należności powstałych z tytułu nieopłaconych składek przez osoby prowadzące pozarolniczą działalność (Dz.U.2012.1551).
} 
automatyczne zwolnienie $\mathrm{z}$ obowiązku zapłaty zaległych składek, niezależnie od przyczyn powstania zadłużenia oraz sytuacji osobistej przedsiębiorcy. Nie negując idei umarzania zaległości składkowych, wydaje się, że ustawodawca zbyt liberalnie potraktował niewywiązywanie się z obowiązku osób pracujących na własny rachunek wobec wspólnoty ubezpieczonych. Ustawa systemowa (art. 28) umożliwia przecież umorzenie należności, rozłożenie ich na raty czy odroczenie terminu płatności w sytuacjach społecznie uzasadnionych, takich jak ciężka choroba czy przejściowy brak środków finansowych. Automatyczne umarzanie zaległości każdemu przedsiębiorcy, bez badania jego stanu rodzinnego, majątkowego, możliwości zarobkowych czy okoliczności, które doprowadziły do zadłużenia, stawia pod znakiem zapytania powszechność i obowiązkowość ubezpieczeń społecznych oraz zasadę solidarności.

Należy wskazać, że powszechna w zasadzie abolicja z 2012 r. była motywowana m.in. chęcią rozwiązania sytuacji prawnej osób prowadzących działalność gospodarczą, które w latach 1999-2009 wykorzystywały przepisy art. 9 ustawy systemowej, czyli tzw. zbiegi tytułów ubezpieczenia, do zmniejszania swoich obciążeń składkowych. Wskazywano, że nie można „karać” ubezpieczonych (będących zarazem płatnikami) za to, że wykorzystali błędy ustawodawcy i zastosowali istniejącą regulację na swoją korzyść (Poselski projekt ustawy o umorzeniu należności powstałych z tytułu niezapłaconych składek na ubezpieczenia społeczne osób prowadzących pozarolniczą działalność gospodarczą, 2012).

Czym innym jest jednak ,wykorzystanie błędów ustawodawcy” w celu obniżenia wysokości składek, a czym innym świadome wprowadzenie w błąd ZUS, a tym samym wspólnoty ubezpieczonych, której interesy zakład reprezentuje, co do okoliczności faktycznych. W praktyce bowiem umowy-zlecenia czy o pracę nakładczą zawierane w latach 1999-2009, mające służyć zwolnieniu przedsiębiorcy z obowiązku opłacania składek w wysokości przewidzianej dla osób prowadzących działalność, były na ogół czynnościami pozornymi, czyli takimi, które nie wywołują skutków prawnych, przy pełnej świadomości obu stron co do tego, że celem umowy było obejście prawa. W odróżnieniu od sytuacji ,przedsiębiorczych matek" nie można tu mówić o problemach z interpretacją przepisów. Nie można też mówić o „błędzie ustawodawcy”, który umożliwił osobom uzyskującym przychody z różnych źródeł wybór tytułu ubezpieczenia, ale przecież tylko spośród tytułów istniejących realnie, a nie jedynie „na papierze”. Abolicja z 2012 r. jest wyrazem pobłażliwego stosunku ustawodawcy do przypadków celowego omijania obowiązku składkowego, a może być uznana wręcz za promowanie tego typu zachowań. Ustawodawca nie zastanowił się nad oddziaływaniem takiej abolicji na psychikę przedsiębiorców, którzy rzetelnie i odpowiedzialnie opłacali składki, bez uciekania się do niezgodnych z prawem i wątpliwych moralnie wybiegów. W takiej sytuacji trudno wymagać, aby w społeczeństwie wykształciło się poczucie współodpowiedzialności za fundusz składkowy. 


\section{Skutki nadużyć w zakresie składek i świadczeń}

Opisane przykłady „optymalizacji składkowej” dotyczą sytuacji, w których przedsiębiorca zaniża składki na własne ubezpieczenie i szkodzi przede wszystkim sobie, obniżając wysokość nie tylko przyszłej emerytury, ale również świadczeń $\mathrm{z}$ tytułu ewentualnej niezdolności do pracy. W szerszej perspektywie działanie takie przynosi szkodę nie tylko wspólnocie ubezpieczonych, ale również wspólnocie narodowej. Jeżeli stan własnego konta ubezpieczonego nie wystarczy na wypłatę co najmniej minimalnej emerytury, to zostanie ona sfinansowana w budżetu państwa. Koszty niefrasobliwości i krótkowzroczności ubezpieczonego poniosą zatem wszyscy obywatele.

Niektóre sposoby optymalizacji prowadzą do pokrzywdzenia ubezpieczonych niebędących jednocześnie płatnikami. Pracodawcy i zleceniodawcy w ramach zasady solidarności współfinansują składki na ubezpieczenia emerytalne i rentowe osób przez siebie zatrudnianych oraz w całości finansują składki na ubezpieczenie wypadkowe, szukają zatem sposobów na uchylenie się od obowiązku opłacania składek. W konsekwencji ubezpieczeni otrzymują zaniżone świadczenia, a w skrajnych przypadkach są ich całkowicie pozbawieni. Brak dostatecznej wiedzy o zasadach funkcjonowania systemu ubezpieczeń powoduje, że pracownicy najemni godzą się na zaniżanie składek, chcąc otrzymywać na bieżąco wyższe wynagrodzenie i aż do chwili wystąpienia ryzyka socjalnego nie zdają sobie sprawy ze skutków takiego wyboru.

Drugą formą nadużyć w systemie ubezpieczeń społecznych jest wyłudzanie świadczeń. W powiązaniu $\mathrm{z}$ nielegalną optymalizacją składkową może to doprowadzić do braku równowagi funduszów ubezpieczeniowych, konieczności większych dopłat z budżetu lub nawet podniesienia procentowej wysokości składek. Inną konsekwencją nadużyć jest kryzys wzajemnego zaufania pomiędzy poszczególnymi podmiotami zaangażowanymi w realizację ubezpieczeń społecznych, co negatywnie oddziałuje na cały system.

\section{Brak wiedzy o ubezpieczeniach społecznych spowodowany niedostateczną edukacją i przekłamaniami medialnymi}

W polskim społeczeństwie poziom wiedzy o ubezpieczeniach społecznych jest niski. Jest to po części spowodowane brakiem odpowiedzialności mediów, które, relacjonując związane z ubezpieczeniami kwestie, nie zawsze przekazują rzetelne i obiektywne informacje. Obiektywnym i systematycznym przekazywaniem wiedzy o organizacji i funkcjonowaniu zabezpieczenia społecznego nie są zainteresowane nawet media publiczne (Szumlicz, 2017, s. 10-11). Przedstawiciele mediów z reguły używają emocjonalnego tonu, a przedstawione fakty dopasowują do założonej z góry tezy. Być może przekłamania te wynikają z chęci przypodobania 
się odbiorcom lub z niedostatecznej staranności dziennikarzy $\mathrm{w}$ analizowaniu prawdziwości uzyskanych informacji ${ }^{5}$.

Jako przykłady podać można cytaty z publikacji portalu Onet.pl dotyczących zjawiska wyłudzania zawyżonych świadczeń z ubezpieczenia chorobowego przez kobiety w ciąży: „ZUS się nie uparł, ale kontrolować lubi. O ZUS-ie, który walczy z kobietami w ciąży, głośno zrobiło się kilka lat temu. Zaczęło się od masowych doniesień o Polkach korzystających z luki w przepisach, które, spodziewając się dziecka, zakładały działalność gospodarczą na minimum miesiąc przed planowaną datą porodu. Następnie deklarowały i przynajmniej raz opłacały najwyższą możliwą składkę ubezpieczeniową, w wyniku czego zyskiwały prawo do odpowiednio wysokich świadczeń z ZUS: zasiłku chorobowego lub macierzyńskiego. Nierzadkie były przypadki, gdy panie, po jednorazowym opłaceniu składki, przez rok pobierały zasiłek macierzyński w wysokości ok. 6 tys. zł”; „Strach padł nie tylko na kobiety prowadzące działalność, ale także na te, które, będąc w ciąży lub niedługo przed tym, zanim w nią zaszły, zostały zatrudnione na umowę o pracę, zwłaszcza jeśli dość szybko po tym fakcie wystąpiły o wypłatę zasiłku chorobowego lub macierzyńskiego. W takim przypadku tłumaczyć musi się nie tylko kobieta, ale i pracodawca. Problem polega jednak na tym, że o ile dla przedsiębiorców to uciążliwość i kolejny przykład na to, że państwo ich nie wspiera, dla wielu kobiet będących w ciąży wszczęcie postępowania wyjaśniającego przez ZUS powoduje, że na wiele miesięcy zostają pozbawione środków do życia." (Groza, 2016). Sformułowanie „ZUS walczy z kobietami w ciąży” jest nadużyciem terminologicznym, odwołującym się do negatywnych emocji. Kolejnym nadużyciem jest określanie wprowadzenia w błąd ZUS co do faktu prowadzenia działalności gospodarczej, zatrudnienia lub wysokości wynagrodzenia jako „korzystania z luki w prawie". Kontrolowanie zasadności wypłacania wysokich zasiłków to dla autora artykułu przejaw „niewspierania” przedsiębiorców. Z perspektywy instytucji ubezpieczeniowej taka kontrola jest przejawem dbałości o środki publiczne oraz o dobro wspólnoty ubezpieczonych. Oczywiście może się zdarzyć, że konieczność dokładnego przeanalizowania okoliczności sprawy opóźni wypłatę zasiłku dla osoby uczciwej, ale to kolejny argument przemawiający za tym, że nadużycia wobec Funduszu Ubezpieczeń Społecznych są działaniami na szkodę wspólnoty, powodują zmniejszenie zaufania instytucji ubezpieczeniowej do beneficjentów systemu i nasilenie kontroli.

Niski poziom wiedzy o ubezpieczeniach społecznych wynika też z niedostatecznego uwzględnienia tej tematyki w ofercie dydaktycznej, w szczególności na kierunkach prawniczych. Ofertę tę przeanalizował A. Sobczyk (2014), zauważając, że tam, gdzie ubezpieczenia społeczne stanowią przedmiot obowiązkowy, organizowany jest wykład z zakresu zabezpieczenia społecznego przy bardzo wysokiej frekwencji, natomiast tam, gdzie wykład nie ma charakteru obowiązkowego - a jest to sytuacja dominująca - ubezpieczenia społeczne stanowią margines merytoryczny lub statystyczny. W piśmiennictwie zwraca się uwagę na ,istotne i unikalne właściwości dydaktyczne, jakie mają ubezpieczenia społeczne

\footnotetext{
${ }^{5}$ Ciekawą analizę tekstów prasowych dotyczących ZUS przeprowadził Maciej Mrozowski (2017,
} s. 49-77). 
w procesie kształtowania prawników. Ubezpieczenia społeczne stanowią jeden $\mathrm{z}$ niewielu praktycznych przykładów znaczenia prawa w procesie zarządzania realizacją wartości (prawo do zabezpieczenia społecznego) przy ograniczonych zasobach. Uczą, w jaki sposób należy wyważać interesy różnych grup z jednoczesnym poszanowaniem interesu innych członków społeczeństwa" (Lasocki \& Bożek, 2017, s. 6-7).

Ideałem byłoby wprowadzenie wiedzy o ubezpieczeniu społecznym do szkolnego programu nauczania co najmniej na poziomie szkoły ponadpodstawowej (Szumlicz, 2014, s. 10-11). Sprzyjałoby to wykształceniu się w młodych ludziach przezorności ubezpieczeniowej i umiejętności racjonalnego korzystania z ochrony ubezpieczeniowej (Łebkowska, 2017, s. 22). W szkołach są nauczane przedmioty, w ramach których mogą pojawić się elementy wiedzy o ubezpieczeniach (wiedza o społeczeństwie, podstawy przedsiębiorczości czy ekonomia w praktyce). W związku z planowaną reformą szkolnictwa zakład skierował do MEN konkretne propozycje zapisów rozszerzających podstawę programową na obu nowych etapach edukacyjnych. Jednak w rozporządzeniu MEN w sprawie nowej podstawy programowej zapis dotyczący treści nauczania przedmiotu wiedza o społeczeństwie w odniesieniu do ubezpieczeń społecznych nie został rozszerzony, a wręcz zawężony w stosunku do wcześniej obowiązującej podstawy (Owsiak, 2017, s. 90-91) $)^{6}$.

\section{Działania ZUS jako instytucji zaufania publicznego odpowiedzialnej za realizację ubezpieczeń społecznych}

Pojawia się pytanie, jakie działania powinien podjąć zakład, aby zbudować w społeczeństwie zaufanie do idei ubezpieczenia społecznego. W jaki sposób wytworzyć lub wzmocnić wśród ubezpieczonych poczucie wspólnoty, którego brak przyczynia się do ucieczki od obowiązku składkowego i powszechnego tolerowania nadużyć dokonywanych na szkodę Funduszu Ubezpieczeń Społecznych?

W grudniu 2015 roku zarząd ZUS przyjął Strategię Zakładu Ubezpieczeń Społecznych na lata 2016-2020, która wsparta została przez strategie obszarowe w dziedzinie komunikacji, obsługi klientów i IT $^{7}$, a której głównym celem jest osiągnięcie przez zakład statusu ,innowacyjnej instytucji zaufania publicznego”. Zakład ma zapewniać sprawną, rzetelną i przyjazną obsługę klientów realizowaną przez kompetentnych pracowników oraz za pomocą nowoczesnych technologii.

\footnotetext{
${ }^{6} \mathrm{~W}$ podstawie programowej przedmiotu wiedza o społeczeństwie dla szkoły podstawowej świadczenia z ubezpieczenia społecznego zostały wymienione tylko jako jedno ze źródeł dochodu rodziny; tematyka ubezpieczeń społecznych uwzględniona została dopiero w podstawie programowej tego przedmiotu dla szkoły branżowej I stopnia; w podstawie programowej przedmiotu podstawy przedsiębiorczości kwestie ubezpieczeniowe zostały pominięte (rozporządzenie MEN z 14.02.2017 r., Dz.U.2017.356 ze zm.).

${ }^{7}$ Strategia komunikacji ZUS - przyjęta w grudniu 2016 r., Polityka Obsługi Klientów - przyjęta w lutym 2017 r., Cyfrowy ZUS - Polityka Rozwoju IT na lata 2017-2022 - przyjęta w marcu 2017. Zob: Społeczna odpowiedzialność ZUS. Raport 2017, s. 14.
} 
Ważnym aspektem jest również przejrzyste i racjonalne gospodarowanie własnymi finansami.

Funkcjonowanie instytucji ubezpieczeniowej w oparciu o przedstawione powyżej założenia powinno przyczynić się do wzmocnienia zaufania nie tylko do niej, ale również do systemu ubezpieczeń społecznych i idei, na której ten system jest oparty. Oczywiście pozytywne zmiany w działaniu ZUS, choć pożądane, mogą okazać się niewystarczające w obliczu zawiłości i niestabilności przepisów ubezpieczeniowych, na kształt których zakład nie ma wpływu.

Zawód zaufania publicznego to zawód wiążący się z (Karwat, 2017, s. 16):

(1) uprawnieniami do uczestnictwa $\mathrm{w}$ procesie decydowania publicznego i uzgadniania jednostkowych interesów, roszczeń i praw z porządkiem prawnym i interesem ogólnospołecznym,

(2) dysponowaniem dobrami publicznymi lub wartościami symbolicznymi konstytutywnymi dla danej wspólnoty,

(3) dostępem do informacji wymagających ochrony.

Analogicznie: instytucja zaufania publicznego to taka, której pracownicy podejmują decyzje dotyczące obywateli z uwzględnieniem interesu społecznego, wiążące się $\mathrm{z}$ dysponowaniem środkami publicznymi i dostępem do informacji podlegających ochronie. Taka instytucja powinna kierować się wartościami powszechnie akceptowanymi w społeczeństwie, takimi jak uczciwość, obiektywizm i rzetelność (Staniszewski, 2017, s. 204).

Działania zakładu w zakresie kształtowania właściwych postaw wobec idei ubezpieczenia społecznego można odnieść do czterech obszarów:

(1) transparentność działania,

(2) racjonalne gospodarowanie finansami,

(3) poszanowanie praw pracowników,

(4) komunikacja i edukacja.

Transparentność działania powinna przejawiać się przede wszystkim w procesie rekrutacji pracowników, zwłaszcza na stanowiska kierownicze, oraz w sferze zamówień publicznych i innych umów zawieranych z podmiotami zewnętrznymi. Ważne jest również, aby pracownicy instytucji ubezpieczeniowej zdawali sobie sprawę z konieczności unikania konfliktu interesów, a także wprowadzenia możliwości anonimowego zgłaszania zjawisk korupcyjnych i innych nieprawidłowości.

Wymagania wobec pracowników instytucji ubezpieczeniowej są takie same, jak wobec innych zawodów zaufania publicznego, a wypełnienie ich jest niemożliwe bez wsparcia tejże instytucji. Innymi słowami: aby pracownicy zakładu mogli rzetelnie i kompetentnie obsługiwać klientów i tym samym dbać o wizerunek pracodawcy, muszą mieć zapewnione właściwe warunki organizacyjne. Zapewnienie pracownikom godziwego wynagrodzenia, dobrych warunków i właściwej atmosfery pracy, jasnej ścieżki awansu, sprawiedliwych zasad premiowania, możliwości podnoszenia kwalifikacji oraz godzenia pracy z życiem rodzinnym jest niezbędne w celu wdrożenia i utrzymania wysokiego standardu obsługi klientów. Jednocześnie lojalność wobec własnych pracowników jest oczywistym obowiązkiem instytucji zaufania publicznego, która od swoich klientów - płatników skła- 
dek - wymaga z kolei rzetelnego wywiązywania się z obowiązków wobec ubezpieczonych.

W dokumencie Społeczna odpowiedzialność ZUS. Raport 2017 przedstawiono działania, które zakład podjął w celu realizacji powyższych założeń. Można tu wskazać przykładowo:

(1) projekt „Sygnaliści”, umożliwiający pracownikom i klientom anonimowe zgłaszanie nadużyć (s. 19, 38, 52),

(2) stosowanie klauzul społecznych w umowach z kontrahentami (s. 29, 40, 52),

(3) wdrożenie „Kodeksu postępowania pracowników ZUS” oraz procedur antymobbingowych (s. 26, 43),

(4) obsadzanie stanowisk kierowniczych w drodze konkursów (s. 28),

(5) zatrudnianie co do zasady na podstawie umów o pracę na czas nieokreślony (s. 34),

(6) dofinansowywanie studiów podyplomowych dla pracowników (s. 36),

(7) dbałość o oszczędne zużycie prądu i wody (s. 47),

(8) promowanie wolontariatu wśród pracowników (s. 76).

W raporcie wymieniono również szereg działań z zakresu edukacji i komunikacji, wśród których na uwagę zasługują dwa projekty - „Lekcje z ZUS” oraz tzw. „prosty język”. W ramach projektu „Lekcje z ZUS”, uruchomionego pilotażowo w październiku i listopadzie 2013 r., uczniowie szkół podstawowych i ponadpodstawowych poznają istotę i historię tworzenia systemów ubezpieczeń społecznych, w tym systemu polskiego, korelacje między poszczególnymi rodzajami ubezpieczeń i zasady solidaryzmu społecznego. Projekt z każdym rokiem obejmuje coraz większą liczbę szkół. W roku szkolnym 2016/2017 wzięło w nim udział 913 szkół i 46.708 uczniów (Owsiak, 2017, s. 97). Efekty takiego działania widoczne będą dopiero po wejściu odpowiednio wykształconej młodzieży na rynek pracy $(\mathrm{Ow}-$ czarek, 2017, s. 164). Oczywiście nie można zakwestionować tezy, że w takich przedsięwzięciach ZUS występuje w roli bezpośrednio zainteresowanego, a to osłabia siłę argumentów i utrudnia zobiektywizowanie przekazu, zatem w proces edukacji ubezpieczeniowej powinno włączyć się państwo, wykorzystując dominującą pozycję w przekazie publicznym (Szumlicz, 2017, s. 11).

W 2016 r. decyzją organizacyjną nr 19 prezesa ZUS powołano zespół roboczy ds. uproszczenia pism, formularzy i wniosków, w ramach którego prace podjęły 4 odrębne podzespoły do spraw (Owsiak, 2017, s. 123):

(1) postępowań,

(2) pism wychodzących (klienci i instytucje),

(3) pism wchodzących (wnioski, formularze, dokumenty ubezpieczeniowe),

(4) informacji, komunikacji i stron www.

W wyniku tych prac uproszczono większość artykułów na stronie internetowej oraz stworzono nowe formularze. Przyjęto też 10 zasad prostego języka w korespondencji z klientami indywidualnymi oraz rozpoczęto prace nad nowymi standardami decyzji oraz innych pism objętych zakresem stosowania Kodeksu postępowania administracyjnego (Społeczna odpowiedzialność ZUS. Raport 2017, s. 18). 
Jak proponuje D. Owczarek (2017, s. 164), ,aby zmienić negatywne postrzeganie ZUS i szerzej ubezpieczeń społecznych, należy przekazem wpływać na emocje odbiorców", a strategia komunikacyjna ZUS powinna odwoływać się do poczucia bezpieczeństwa, stabilności i pewność wypłaty świadczeń, wykorzystując do tego celu długotrwałą tradycję ZUS i ciągłość tej instytucji bez względu na zawirowania historyczne. Autor ten podkreśla, że bardzo ważne jest szybkie i sprawne reagowanie na nieprawdziwe informacje pojawiające się $\mathrm{w}$ mediach na temat ZUS lub systemu zabezpieczenia społecznego z wykorzystaniem mediów szerokiego zasięgu.

\section{Podsumowanie}

Zakład Ubezpieczeń Społecznych konsekwentnie wdraża działania, mające na celu upowszechnienie wiedzy o ubezpieczeniach, uświadomienie ryzyka, wzmocnienie poczucia wspólnoty i współodpowiedzialności za fundusz składkowy. Działania te w większości mają charakter długofalowy i ich efektu należy oczekiwać w dłuższej perspektywie czasowej.

Aby odniosły skutek, wskazane byłoby większe zaangażowanie państwa w edukację ubezpieczeniową, w szczególności poprzez uwzględnienie kwestii związanych $\mathrm{z}$ ubezpieczeniem społecznym $\mathrm{w}$ programie nauczania.

Wskazana jest też poprawa techniki legislacyjnej przy tworzeniu i nowelizowaniu przepisów z zakresu ubezpieczeń społecznych. Ustawodawca powinien rozważyć dogłębne zmiany systemowe zamiast doraźnych działań i zadbać przede wszystkim o pewność i stabilność prawa w tej dziedzinie.

\section{Bibliografia}

Felis, P., \& Szlęzak-Matusewicz, J. (2018). Optymalizacja podatkowa - możliwości a realizacja. W: M. Wrzesiński, J. Ostaszewski (red.), Etyka, sprawiedliwość $i$ racjonalność $w$ dorobku nauki o finansach $w$ latach 1918-2018 (s. 85-112). Warszawa: SGH Oficyna Wydawnicza.

Groza, A. (2016). ZUS zabiera świadczenia, a kobiety w ciąży zostaja bez środków do życia. https://kobieta.onet.pl/dziecko/ciaza-i-porod/ciaza/zus-zabieraswiadczenia-a-kobiety-w-ciazy-zostaja-bez-srodkow-do-zycia/4h23618

Jędrych, E., \& Berniak-Woźny, J. (2018). Ksztattowanie kapitału społecznego organizacji. Warszawa: Wydawnictwo Naukowe PWN.

Karwat, M. (2017). Zawody zaufania publicznego. Interpretacja pojęcia. W: J. Itrich-Drabarek (red.), Etyka sfery publicznej (s. 13-29). Warszawa: Elipsa.

Lasocki, T., \& Bożek, D.R. (2017). Ubezpieczenia społeczne w ofercie dydaktycznej wydziałów prawa uczelni wyższych. Ubezpieczenia Społeczne. Teoria i praktyka, 1, 39-47. 
Łączak, A. (2018). Etyka w biznesie czy biznes w etyce? W poszukiwaniu współczesnych granic między etyką a biznesem. W: M. Wrzesiński, J. Ostaszewski (red.), Etyka, sprawiedliwość i racjonalność $w$ dorobku nauki o finansach $w$ latach 1918-2018 (s. 47-59). Warszawa: SGH Oficyna Wydawnicza.

Łebkowska, M. (2017). Edukacja ubezpieczeniowa młodzieży ponadgimnazjalnej w systemie szkolnym i poza nim. Ubezpieczenia Społeczne. Teoria i praktyka, 1, 17-38.

Marczak, R. (2016). Wiedza i postawy wobec ubezpieczeń społecznych. Raport z badań. Warszawa: ZUS, ISP.

Mrozowski, M. (2017). Zakład Ubezpieczeń Społecznych w mediach, media o ZUS. Kształtowanie wizerunku instytucji i wiedzy o systemie ubezpieczeń społecznych. Ubezpieczenia Społeczne. Teoria i praktyka, 1, 49-78.

Owczarek, D. (2017). Niski poziom wiedzy a wyrazista postawa Polaków wobec ubezpieczeń społecznych i Zakładu Ubezpieczeń Społecznych. Ubezpieczenia Społeczne. Teoria i praktyka, 1, 153-170.

Owsiak, B. (2017). Popularyzowanie wiedzy o ubezpieczeniach społecznych przez Zakład Ubezpieczeń Społecznych. Ubezpieczenia Społeczne. Teoria i praktyka, 1, 79-138.

Poselski projekt ustawy o umorzeniu należności powstałych z tytulu niezaptaconych składek na ubezpieczenia społeczne osób prowadzacych pozarolnicza działalność gospodarcza. Druk sejmowy nr 382, VII kadencji. http://www. sejm.gov.pl/Sejm7.nsf/PrzebiegProc.xsp?nr=382

Sobczyk, A. (2014). W sprawie kryzysu edukacji z zakresu ubezpieczeń społecznych na studiach prawniczych. Ubezpieczenia Społeczne. Teoria i praktyka, 2, 14-18.

Społeczna odpowiedzialność ZUS. Raport 2017. https://www.zus.pl/documents/1 0182/167526/ZUS_CSR_2017.pdf/1d4555d1-4031-66fc-af92-6512636846df

Staniszewski, R. (2017). Etyka zawodowa pracowników sektora bankowego - pomiędzy maksymalizacją zysków a zaufaniem publicznym. W: M. Itrich-Drabarek (red.), Etyka sfery publicznej (s. 198-224). Warszawa: Elipsa.

Stanowisko RPO w sprawie P 20/16. https://www.rpo.gov.pl/sites/default/ files/Stanowisko\%20RPO\%20dla\%20TK.pdf

Strategia Zakładu Ubezpieczeń Społecznych na lata 2016-2020. (2015). https://www. zus.pl/o-zus/o-nas/strategia-zus/strategia-rozwoju-zus-na-lata-2016-2020

Szumlicz, T. (2017). Świadomość ryzyka społecznego jako podstawa wiedzy o systemie ubezpieczeń społecznych. Ubezpieczenia Społeczne. Teoria i praktyka, 1, 3-16.

World Values Survey, wave 6 2010-2014. http://www.worldvaluessurvey.org/ WVSDocumentationWV6.jsp 